\title{
Inconsistencies of Traditional Village Policy in Banyumas Regency
}

\author{
Sofa Marwah \\ Department of Political Science \\ UniversitasJenderal Soedirman University \\ Purwokerto, Indonesia \\ sofamarwah75@gmail.com
}

\begin{abstract}
This research and community service-based paper aim at assessing sustainability of the preservation program of five traditional villages in Banyumas in the context of the implementation of The Law No. 6 of 2014. Banyumas has five traditional villages, namely Pekuncen, Cikakak, Kalisalak, Gerduren and Pasir Wetan set by Ministry of Home Affairs in 2011. This research was conducted using qualitative research methods. Then, through Community Service Program,the management training and budgeting of the preservation program of five villages in Banyumas are conducted. The results showed Banyumas Government lacks a clear vision of sustainability related to the preservation of traditional village. It proven from the unclear source funding of the development of traditional villages.Now, five traditional villages are at a crossroads, between there is not any continuity of preservation program and integrating the preservation of customs and culture in the implementation of The Law No. 6 of 2014
\end{abstract}

Keywords—preservation programs, policies, traditional villages, The Law No. 6 of 2014

\section{INTRODUCTION}

Decentralization which is created in Reform Era issues many varied culture policies. This is different from New Order Period which was centralistic that the government defined, planed, managed, and determined the cultural policies or practices. Moreover, the cultural policies during New Order Period caused the diversity of customs, cultures, languages, and village institution vanished. Thus, it can be said that the characteristics and the autonomy of the villages have disappeared because of the national development.

In Reform Era, once more, villages based on customs are acknowledged by the government system, and they are known as traditional villages. The authority because of the decentralization encourages areas to manage its own potencies which are previously gone during New Order Period. Hence, in the village level, this kind of condition causes village communities form their own local governments which are autonomy and based on their own characteristics [1].

In this present government, the commitment to protect and recognize traditional communities is in Nawacita programs of President Joko Widodo. Besides, one of the priorities of Nawacita is to make sure that The Law No. 6 of 2014 on Village can be well conducted especially on how the province and regency/municipality government manage traditional communities to be traditional villages. This kind of condition is clearly shown in chapter XIII in The Law No.6 of 2014 on Village. Then, these traditional communities that can be changed into traditional villages must exist whether the existence is about the territory, genealogies, and function. Furthermore, traditional community units must also be in line with the development of the societies and the principal of Indonesian country as the unity in diversity country.

Therefore, this study is going to review cultural policies in Banyumas regency focusing more on managing the sustainability of traditional villages. This is also about the decision on five villages in Banyumas Regency as the traditional villages set byKementrian Dalam Negeri or the Ministry of Home Affairs in 2011. Nevertheless, there is not any sustainability of the policy program in areas where pilot project conducted. Thus, although The Law No. 6 of 2014 on Village in village level can be the basic regulation to maintain the villages, the law is not applied by the regency to sustain those five traditionalvillages.

\section{RESEARCH METHODS}

This paper is based on the result of a study using qualitative approach as phenomena can be observed more detail and accurate. The informants were chosen based on the criteria of the study using purposive technique. The data collection is done through combination of deep interviews, document studies, and observations. Finally, the data analysis is started by clarification, theoretical abstraction on information and facts to get basic statements [2].

This paper is also based on community services program in the form of management trainings and budgeting on the development program for the traditional villages. The activities on the community service programs are conducted by trainings to support the local government institutions to manage and plan the program of preserving customs and culture.The activities for the local governments and societies are also done persuasively to make them be together in maintaining the origin structures, customs, and culture independently. 


\section{RESULT AND DISCUSSION}

\section{A. Five Villages in Banyumas Regency Set As Traditional Villages by Ministry of Home Affairs}

Village is the smallest government unit in Indonesia which has certain rights. In New Order Period, village is managed in The Law No. 5 of 1979 on Village which states that there is only one form of local government, and there is no diversity on villages based on customs. That time, all government structure in the lowest bureaucracy level was called by desa or kelurahan following structure applied in Java Island [3].

Based on the law, then, village is the smallest law unit where communities can organize their own governments. When the Law No. 6 of 2014 has been enacted, the law gives opportunity to strengthen autonomy indigenous societies to possess and manage their own natural resources in their regions. The traditional villages admitted by the law have their own local governments which are preserved hereditary. Besides, these governments are protected by the leader and indigenous societies, so they can develop the prosperity and identity of local cultures.

The difference between villages and traditional villages is the application of the rights which are about preserving traditional villages, managing and organizing traditional areas, conducting traditional court, keeping the safeties and orders of traditional societies, and implementing local governments based on their own structure. The spirit to re-enact this local governments has a meaning that there is a union of two functions, based on The Law No. 6 of 2014, there are: 1) selfgoverning community or conducting the authority as local government based on rights and authorities in village level; 2) local self goverment which is the authority given by government, province government, and regency government [4].

Banyumas Regency is one of regions which have distinct diversity of customs and culture. Marwah study shows these distinct customs and culture in Banyumas. The example of these distinct customs and cultures is done by a community group that holds jamasan jimat, sujarahan, rasullan and traditions in Kalisalak Village in Kebasen District. Jamasan is about the journey led by Amangkurat I a king from Mataram to Batavia that left some weapons, scripts, and cloths in Kalisalak. Until this present moment, those things are still in Langgar Jimat, and they are considered as talismans. Besides that, Kalisalak community also has tradition, such as, gubrak lesung, rengkong or the way to keep un-hulled rice. Finally, they also have a traditional house called by srotong and tikelan.

Another example is a group community in Pekuncen Village in Jatilawang district. They are the ancestry of Bonokeling who are believed as an Islam massager in Jatilawang. The ancestry of Bonokeling, then, combines traditional ritual and Muslim prayer. They also have leaders called by bedogol. These bedogol consist of five people who identify themselves as Pandhawa. They have a ritual named unggah-unggahan right beforeRamadan and perlon right after Ramadhan.
Then, Banyumas also has an indigenous society known as Islam Aboge(Islam Alip Rebo Wage). They are the offspring of Mbah Tholih; moreover, they live in Cikakak Village in Wangon District. They also have a sacred mosque called by Masjid Saka Tunggal. In Rajab Month, the community conducts jaroh rojab, a tradition done by replacing the wall of the mosque. Other traditions carried out by Islam Aboge are grebeg tumpeng rajaban, and ritual apitan.

The next community is a community which has bond with Pasirluhur Kingdom. In the past, the kingdom was the spread center of Islam, and today the community in Pasirwetan Village is its representation. The history of Pasirluhur and the development of Islam in that area are told in Babad Pasir; [5] also, until this present moment, the people in Pasirwetan are blacksmiths. Finally, the last community is in Gerduren Village in Purwojati District. The community is the center of lengger; furthermore, they give respect to lengger dancers by asking blessing from the dancers. The existence of lengger is supported by doing rituals done by the doers of the ceremony and the traditional music named calung.

Hence, as those five villages have distinctive customs, in 2011, the Ministry of Home Affairs set them as traditional villages. The decision was based on the Ministry of home affairs regulation No. 52 of 2007 on the guidance of preserving and developing customs and social values of community culture. Besides, setting those five villages, the Ministry of Home Affairs also decided that other 42 villages are also traditional villages.

As the continuity of the program, the Ministry of Home Affairs approved pilot projects on preserving customs and culture. It was conducted from 2012 until 2014. In Banyumas Regency, the pilot project is under Badan Pemberdayaan Masyarakat, Perempuan dan Keluarga Berencana (Bapermas $P K B)$ or The Board of Community Empowerment, Women and Familiy Planning. Bapermas $P K B$ in Banyumas is a leading sector to enact the project done in those five villages.

To make the program succeeds the Ministry of Home Affairs in 2012 passes technical instructions determining villages and Pokmas as the guidance of activities that preserve customs and cultures in those five traditional villages. Based on this, technical instruction guidance on preserving customs and cultures activities was arranged by Pokmas, a society group formed in local level as the manager of pilot project in each of the traditional village. Those are:1) strengthening the authority of the institutions; 2) training and preserving local customs and cultures; 3) supporting customs and cultures; 4) making village regulations on preserving customs and cultures; 5) constructing village history; 6) strengthening women role throughPembinaan Kesejahteraan Keluarga(PKK) orThe Building of Family Welfare; 7) empowering economy and society institution [6].

After three years conducting the program, there is not any continuity of the program proven by no specific fund to carry on it. Moreover, Bapermas PKB in Banyumas also did not allocate the fund for preserving customs and culture on those five traditional villages. 


\section{B. Inconsistency in DevelopingTraditional Villages Based on} The Law No. 6 of 2014

When the Law No.6 of 2014 on Village began to be implemented, Bapermas PKB has its authority to be leading sector under Kementrian Desa, Pembangunan Daerah Tertinggal dan Transmigrasi or The Ministry of Rural, Development of Disadvantaged Regions and Transmigration. Therefore, Bapermas $P K B$ in relation to implement The Law No.6 of 2014 must give specific attention to preserve customs and cultures in Pekuncen, Kalisalak, Cikakak, Pasirwetan, and Gerduren village. This is necessary as the continuation of pilot project of the Ministry of Home Affairs for three years on those villages. Unfortunately, the government in Banyumas Regency only issues Regency Regulation about nature preservation which lacks of support to make those five villages become traditional villages. Moreover, the government does not specifically issue the regulation on budgeting for preserving customs and cultures in those five villages.

Then, if we see the criteria on indigenous society units that can be changed into traditional villages based on The Law No.6 of 2014 on Village, it is necessary to be studies further whether those five traditional villages which are got the status from the Ministry of Home Affairs fulfill the requirements as the traditional village. Sometimes, because of development policies, we face obstacles as they create different perspectives. In this study, the Ministry of Home Affairs has its own definition on traditional villages; however, when The Law No.6 of 2014 was published, the law also has its own definition about the issue. It is important to be understood that New Order Era destroys the real structure of village that is so diverse; hence, the meaning of traditional villages is difficult to be translated in Reform Era.

The Law No.6 of 2014 on Village clearly states that these traditional societies that can be changed into traditional villages must exist whether the existence is about the territory, genealogies, and function. Furthermore, this unit with its traditional privileges must have territory and must fulfill one or more on several requirements, such as: 1) having the same togetherness feeling as a society group; 2) having local institution; 3) having wealth and/or custom objects; 4) having customary law norms institution. In the context managing traditional villages completely, each of government function, both executive and legislative, is carried out in line with the real traditional village institutions. In local level, the complete management of the traditional villages is assigned through the assessment based on local regulation.

Even though those five traditional villages in Banyumas Regency cannot accomplish the criteria of The Law No.6 of 2014, the commitment of Bapermas PKB gives special attention on the possibility that those five villages may get budget to preserve the customs and cultures. There is one more important thing needed to be done by Bapermas PKB which is about supporting local government to integrate the budget for preserving customs and cultures in APBDes or village budget, and encouraging Pokmas to organize local customs and cultures.

The Project Supported by University Excellence Research, Jenderal Soedirman University, 2014 and Community Services Program IbM Dikti, 2015.
As it is known, The Law No.6 of 2014 allows villages to manage APBDes based on the need in very huge amount of money. In budgeting, a village gets the income from its own revenue and the transfer. The transfer fund consists of: 1) APBN; 2) local tax and retribution; 3) ADD or village fund which is the balance fund got by regency/district in their APBD after it is reduced by DAK (special allocation fund); 4) financial assistance from province APBD; 5) financial assistance from regency/district APBD. The chance of those traditional villages to manage their own budget let them have their own fund to preserve their customs and cultures. APBDes structure is: 1) village income; 2) village expense; 3 ) village cost. For expense, there are: 1) village government management; 2) village development program; 3) village social training 4) village empowerment community; 5) unexpected expense. Thus, the attempt to preserve customs and cultures may be put in village social training or village empowerment community.

This kind of condition empowers Pokmas to be involved more as Pokmas has been formed since pilot project conducted by the Ministry of Home Affairs. Pokmas is a group of society which is designed to manage preserving customs and culture in village level enacted by Banyumas Regent Decree No. 414.4/195/2011. Here are Pokmas which is created in each of the traditional village: 1) Pokmas Bonokeling in Pekuncen Village; 2) Pokmas Saka Tunggal in Cikakak Village; 3)Pokmas Mandala Kaloka in Kalisalak Village; 4) Pokmas Gerduren in GerdurenVillage; 5) Pokmas Pasir Luhur in Pasir Wetan Village. Hence, the empowering Pokmas is an attempt to support actions and institutions' decisions that concern about preserving customs and cultures. Finally, that empowerment causes the increasing Pokmas' functions as the group that preserves customs and cultures

Then, Marwah conducted Community Services IbM in 2015 as her respond on the conditioned which has been explained. Some important trainings done in that service carried out to increase Pokmas knowledge on how the institution can include the budget for preserving customs and cultures in APBDes. It is very crucial for Pokmas to have that ability to submit the budgeting for preserving customs and cultures through APBDes making process. APBDes ideally is vision and mission of the chef village. This vision and mission is going to be carried out in the form of village mid-term development plan (RPJMDes) which is enacted through village regulations. Then, RPJMDes is going to be translated in development activity plan (RKP) through Musrenbangdes. This $R K P$ becomes the basic of RAPBDes making which is arranged by village secretary. RAPBDes can become APBDes after ratifying by $B P D$, and $A P B D e s$ which is have be ratified is going to be given to the regent.

Another important thing in that training was the attempt to increase the authority of Pokmas to do mapping and searching the community potencies in order to preserve customs and cultures. Pokmas in each village must have that kind of ability to make each of traditional village survives. In the process of searching the potencies on customs and cultures, there are some things that can be the references of 
Pokmas, and they are:

1) Involving in the making of layouts and village social maps;

2) Educating in traditional health;

3) Establishing and managing art galleries, studio studies, or village libraries;

4) Maintaining cemetery, remains of the past and cultural heritages;

5) Developing tourism culture village;

6) Managing rivers, village forests, and other living environments;

7) Maintaining on peace, harmony, conflicts, and mutual cooperation;

8) Conducting traditional village festivals, or culture tours;

9) Involving Pokmas in the making of customs and cultures curriculums;

10) Doing study on cultures with universities [7].

\section{CONCLUSION}

Government policies on cultures tend to change from time to time, and it causes the inconsistency on preserving customs and cultures. The inconsistency is also caused by the different perspective on what traditional villages are and what institutions which take charge on the program. Politically, that condition can be said as the impact of New Order Era as in that era centralization was applied.

However, the decentralization opens regions which have potencies on customs and culture to be developed. Thus, Banyumas Regency which has distinctive customs and cultures needs to persevere and develop the potencies. Moreover based on The Law No.6 of 2014 on Village, regencies have opportunity to assist villages to plan and conduct development program on preserving customs and cultures. The assistance of the traditional villages in Banyumas Regency, namely, Pekuncen, Cikakak, Kalisalak, Gerduren and Pasirwetan can be done by Bapermas PKB, so those villages which are set by the Ministry of Home Affairs can manage their budget on the preservation customs and cultures. Besides, Bapermas PKB can encourage Pokmas to strengthen its roles as the management of local customs and cultures. In the local level, the commitment to conduct the regulation will certainly assure the result to preserve and develop customs and cultures of those five traditional villages. Therefore, in the condition mentioned, the continuity of preserving customs and cultures that has been done since of five years ago was not in the crossroad.

Community to make them committed, consistent and responsible for compliance with applicable pamali system.Second, to maintain activity Manuba Ba Adat, not just rely on social capital owned by the local community but all stakeholders in the district Lamandau should be mutually supportive.

\section{ACKNOWLEDGMENT}

The author would like to thank the Foundation Kotawaringin Antakusuma University, Rector of the Antakusuma University, Lamandau District Government for financial support and Dr. Giri Pamerdi Wiloso, M.Si the criticism and suggestions that have been given.

\section{REFERENCES}

[1] Alamsyah, M.N. 2011. "Memahami perkembangan desa di Indonesia"("Understanding for the increasing of village in Indonesia"), Academica Journal Untad, Vol 3 No. 2 October.

[2] Silbergh, D.M. 2001. Doing dissertations in politics: a student guide, London: Routledge.

[3] Nuraini, S. 2010."Hubungan kekuasaan elit pemerintahan desa"("The Power relation of village government's elites"), Kybernan Journal Unisma Vol 1 No.1.

[4] Nuraini, S. 2010."Hubungan kekuasaan elit pemerintahan desa"("The Power relation of village government's elites"), Kybernan Journal Unisma Vol 1 No.1.

[5] Priyadi, S. 2008."Babad Pasir, Islamisasi, dan Perdikan Pasir" ("Babad Pasir, Islamization and Perdikan Pasir"), Tajdid Journal, October.

[6] Marwah, S. 2015. "Representasi sejarah dan tradisi kuno Banyumas: Antara peran perempuan dan pelestarian adat olehnegara" ("Historical and customs representation of Banyumas:Between the role of women and preservation customs by state"),Paramita Journal Unnes Vol1.25 January.

[7] Marwah, S. 2016. "Traditional village in policy order of village government in Indonesia”, Conferences proceeding of Internasional Conference on Education and Social Sciences, High Education Forum, Singapore. 